\title{
Analisis Vegetasi Gulma Pada Lahan Pertanaman Kacang Kedelai (Glycine max L. Merill)
}

\author{
Analysis Of Weed Vegetation On Field Of Soybean (Glycine max L. Merill)
}

\author{
Annisa Tiara Ramadani*, Hanny Hidayati Nafi'ah, Siti Syarah Maesyaroh \\ Prodi Agroteknologi, Fakultas Pertanian, Univesitas Garut \\ Jalan Raya Samarang Nomor 52.A, Garut \\ *annisatiarara29@gmail.com
}

\begin{abstract}
Abstrak
Pengendalian gulma yang tepat merupakan faktor penentu keberhasilan budidaya tanaman pertanian. Efektifitas teknik pengendalian gulma sangat tergantung pada jenis gulmanya. Penelitian terhadap analisis vegetasi gulma pada lahan pertanman kacang kedelai telah dilakukan selama 3 bulan terhitung Agustus hingga november 2020. Metode kuadran digunakan dalam penelitian ini yaitu identifikasi gulma, menghitung nilai penting, Summed Domminance Ratio (SDR), Indeks keanekaragaman (H'). Hasil penelitian menunjukan terdapat 10 jenis gulma Cynodon dactylon L., Eleusine indica L., Ischaemum rugosum, Cyperus rotundus, dan Cyperus difformis L., Amaranthus spinosus L., Commelina diffusa Burm F., Marselina minuta., Portulaca oleracea L., dan Alternanthera sp. Nilai indeks keanekaragaman (H') masuk kedalam kategori rendah yaitu $<1(0,15)$ jenis gulma Cynodon dactylon L..
\end{abstract}

Kata kunci: Analisis Vegetasi, Identifikasi, Indeks Keanekaragaman, Gulma.

\begin{abstract}
Proper weed control is a determining factor for the success of agricultural crop cultivation. The effectiveness of weed control techniques is highly dependent on the type of weed. Research on the analysis of weed vegetation on soybean farms has been carried out for 3 months from Agustus to November 2020. The quadrant method used in this study is weed identification, calculating important value, Summed Domminance Ratio (SDR), diversity index $\left(H^{\prime}\right)$. The results showed that there were 10 types of weeds Cynodon dactylon L., Eleusine indica L., Ischaemum rugosum, Cyperus rotundus, and Cyperus difformis L., Amaranthus spinosus L., Commelina diffusa Burm F., Marselina minuta. , Portulaca oleracea L., And Alternanthera sp. The diversity index value $\left(H^{\prime}\right)$ falls into the low category, namely $<1$ (0.15) species of Cynodon dactylon L. weed.
\end{abstract}

Keywords: Identification, Diversity Index, Vegetation Analysis, Weed.

\section{Pendahuluan}

Kedelai (Glycine max L. Merill) merupakan salah satu komoditas pangan yang penting di Indonesia yang memiliki kandungan protein tinggi. Pemanfaatan kedelai 
disamping sebagai bahan pangan juga sebagai bahan baku agroindustri. Data Badan Pusat Statistik menyebutkan bahwa produktivitas kedelai pada tahun 2012 masih rendah, yaitu 1,4 ton/Ha. Oleh karena itu Pemerintah Indonesia mengambil kebijakan untuk melakukan impor guna memenuhi kesenjangan antara produksi dan konsumsi dalam negeri. Pada tahun 2012, total produksi kedelai dalam negeri adalah 0,78 juta ton dan impor kedelai Indonesia 2,4 juta ton (Kompas, 2012).

Salah satu faktor penyebab berkurangnya produksi tanaman kedelai ialah gulma. Gulma adalah tumbuhan yang tumbuh tidak pada tempatnya yang dapat merugikan tanaman budidaya sehingga manusia berusaha untuk mengendalikannya. Kerugian yang ditimbulkan di bidang usaha tani adalah menurunkan hasil, menurunkan mutu, dan menambah biaya produksi (Sembodo, 2010).

Gulma menjadi tumbuhan pengganggu yang menjadi pesaing bagi tanaman budidaya, baik dalam hal pemanfaatan ruang, cahaya maupun dalam hal penyerapan air dan nutrisi. Kehadiran gulma pada pertanaman kedelai tidak dapat dihindarkan, sehingga terjadi kompetisi dan kandungan alelopati. Alelopati adalah interaksi antarorganisme yang mana keberadaan satu organisme dapat menghambat pertumbuhan atau perkembangan organisme lainnya melalui pelepasan toksin atau racun. Penurunan hasil akibat gulma pada tanaman kedelai dapat mencapai 30 - 50\% (Sebayang, 2004).

Keragaman gulma dipengaruhi oleh kondisi lingkungan (Perdana, 2013). Banyak faktor yang mempengaruhi keragaman gulma pada tiap lokasi seperti pengamatan, cahaya, unsur hara, serta jarak tanam atau kerapatan tanaman yang digunakan berbeda serta umur tanaman kedelai tersebut. Spesies gulma juga dipengaruhi oleh kerapatan tanaman, kesuburan tanah, pola budidaya dan pengolahan tanah (Aldrich, 1997).

Tujuan penelitian ini yaitu untuk Mengetahui tingkat keanekaragaman gulma pada lahan pertanaman kacang kedelai dan Mengetahui gulma dominan pada lahan pertanaman kacang kedelai.

\section{Metodoogi}

Penelitian ini dilaksanakan di lahan percobaan Fakultas Pertanian Universitas Garut Jl. Hampor, Rancabango, Kec. Tarogong Kaler Kabupaten Garut Bulan Agustus sampai November 2020. Lahan percobaan Fakultas Pertanian Universitas Garut berada pada ketinggian 732 meter di atas permukaan laut (Mdpl). Luasan lahan $\pm 14 \mathrm{~m} \mathrm{x} \mathrm{3m} \mathrm{dengan}$ jarak tanam kedelai $40 \mathrm{~cm}$ x $15 \mathrm{~cm}$. Objek penelitian yang digunakan adalah tanaman kedelai sedangkan alat yang digunakan pada penelitian ini adalah Kuadran Bambu berbentuk persegi dengan ukuran 0,5 m x 0,5 m, Gunting, Kantong plastik, Timbangan analitik, Kantong kertas, Alat tulis, Penggaris.

Metode yang digunakan mencakup kualitatif (weed survey) dan kuantitatif (identifikasi). Setiap lokasi sample dilakukan analisis vegetasi gulma secara diagonal (5 kali) untuk setiap luasan lahan pertanaman kedelai dengan metode kuadran. Pemasangan sample dilakukan sebanyak 210 buah pada 42 bedengan. Pengambilan sampel dilakukan 2 minggu sekali. Ukuran kuadran yang digunakan $0,5 \mathrm{~m}$ x 0,5 m. Setiap spesies gulma 
yang terdapat pada petak kuadran diidentifikasi berdasarkan spesies, kemudian dihitung jumlahnya dan ditimbang bobot keringnya. Data yang diperoleh dari hasil penentuan frame digunakan untuk menghitung tingkat keanekaragaman Gulma dengan terlebih dahulu menentukan nilai penting dan indeks keanekaragaman, sedangkan untuk menghitunng dominasi gulma terlebih dahulu menentukan bobot kering dan summed dominance ratio (SDR) dengan formula sebagai berikut:

a) Nilai Penting Gulma ( NP) adalah nilai kenting yang diperoleh dari perhitungan sebagaimana dikemukakan oleh Chaves dan Bhandari (1982), yaitu:

Kerapatan relatif suatu jenis $=\frac{\text { nilai suatu kerapatan satu golongan }}{\text { Enilai kerapatan mutlak semua golongan }} \times 100 \%$

Frekuensi relatif suatu jenis $=\frac{\text { nilai frekuensi mutlak satu golongan }}{\text { Enilai frekuensi mutlak semua golongan }} \times 100 \%$

Dominasi relatif suatu jenis $=\frac{\text { nilai dominasi mutlak satu golongan }}{\text { Enilai dominasi mutlak semua golongan }} \times 100 \%$

b) Indeks keanekaragaman Shannon -Wiener. Indeks keanekaragaman ShannonWiener yang digunakan memiliki Formula Sebagai berikut: H'= - (NP satu jenis/Np seluruh jenis $) \times(\log (\mathrm{NP}$ satu jenis/Np seluruh jenis $))$.

c) Summed Dominance Ratio (SDR) adalah parameter yang digunakan untuk menyerahkan tingkat dominasi spesies-spesies gulma dalam suatu komunitas. Summed Dominance Ratio (SDR) memiliki formula sebagai berikut:Summed Domminance Ratio $(\mathrm{SDR})=\frac{\text { Nilai } \text { Penting }}{3}$

\section{Hasil dan Pembahasan}

\section{Identifikasi Gulma}

Berdasarkan Hasil Analisis Vegetasi gulma pada lahan pertanaman kedelai Menunjukan bahwa jenis gulma yang teridentifikasi secara umum tercatat ada 10 jenis gulma. Data hasil identifikasi dapat dilihat pada Tabel 1. Data pada Tabel 1 menunjukkan bahwa spesies gulma yang termasuk ke dalam gulma rumput terdapat 3 spesies, yaitu: Cynodon dactylon L., Eleusine indica L., Ischaemum rugosum. Tercatat 2 spesies gulma teki, yaitu: Cyperus rotundus dan Cyperus difformis L. Serta terdapat 5 spesies gulma berdaun lebar, yaitu: Amaranthus spinosus L., Commelina diffusa Burm F., Marselina minuta., Portulaca oleracea L., dan Alternanthera sp.

Banyaknya jenis gulma yang tumbuh di pertanaman tersebut dapat disebabkan karena adanya tindakan pengolahan tanah dan input pupuk kandang. Jumlah jenis gulma terbanyak dari hasil diidentifikasi adalah jenis gulma berdaun lebar, yaitu sebanyak 5 jenis, dimungkinkan karena lahan yang cocok untuk pertumbuhan gulma jenis ini. Menurut Tjitrosoepomo (1987), Golongan gulma berdaun lebar menyukai tanah sedikit lembab, sedangkan gulma jenis teki dan rumput lebih menyukai lahan terbuka. Di sekitar pertanaman kacang kedelai merupakan lahan yang lembab karena ternaungi oleh tanaman Refugia dan Pertanaman Kedelai.

\section{Nilai Penting}


Indeks Nilai penting (INP) dipakai untuk mengetahui dominasi suatu jenis terhadap yang lainnya. Dengan kata lain INP dapat memberikan gambaran mengenai kedudukan ekologis suatu jenis gulma didalam suatu komunitas. Dominasi suatu jenis gulma dapat diketahui dari Indeks nilai pentingnya.

Tabel 1. Identifikasi Gulma pada Lahan Pertanaman Kacang Kedelai.

\begin{tabular}{ccc}
\hline No & $\begin{array}{c}\text { Gulma } \\
\text { Rumput }\end{array}$ & Nama Lokal \\
\hline 1 & Cynodon dactylon L. & Grintingan \\
2 & Eleusine indica $\mathrm{L}$. & Belulangan \\
3 & Ischaemum rugosum & Blembem \\
& Teki & Teki Ladang \\
4 & Cyperus rotundus & Wudelan \\
5 & Cyperus difformis $\mathrm{L}$. & \\
& Daun Lebar & Semanggi \\
6 & Marselina minuta $\mathrm{L}$. & Bayam Berduri \\
7 & Amaranthus spinosus $\mathrm{L}$. & Brambangan \\
8 & Commelina diffusa Burm & Gelang \\
9 & Portulaca oleracea $\mathrm{L}$. & Kremah \\
10 & Alternanthera sp. &
\end{tabular}

Semakin tinggi INP suatu spesies maka semakin besar penguasaanya dalam komunitas. Suatu komunitas dikatakan mendominasi apabila kehadirannya mengendalikan jenis lain di dalam komunitas tersebut (Rosanti, 2012).

Tabel 2. Nilai Penting Gulma Kedelai-Refugia pada Lahan Pertanaman Kacang

Kedelai.

\begin{tabular}{lcccc}
\hline \multicolumn{1}{c}{ Spesies } & KR(\%) & FR(\%) & DR(\%) & INP \\
\hline Cynodon dactylon L. & 65,62 & 18,75 & 54,55 & 138,92 \\
Cyperus rotundus & 24,00 & 18,75 & 25,86 & 68,61 \\
Alternanthera sp. & 4,57 & 12,50 & 5,84 & 22,92 \\
Eleusine indica L. & 0,07 & 3,12 & 0,16 & 3,35 \\
Commelina diffusa Burm.F. & 0,04 & 3,12 & 0,05 & 3,22 \\
Portulaca oleracen L. & 0,69 & 9,37 & 1,44 & 11,50 \\
Amaranthus spinosus L. & 0,04 & 6,24 & 6,03 & 12,33 \\
Marselina minuta L. & 1,58 & 12,50 & 2,48 & 16,56 \\
Ischaemum rugosum Salisb. & 0 & 3,12 & 0 & 3,12 \\
Cyperus difformis L. & 3,34 & 12,50 & 3,57 & 19,41 \\
\hline \multicolumn{1}{c}{ TOTAL } & $\mathbf{1 0 0}$ & $\mathbf{1 0 0}$ & $\mathbf{1 0 0}$ & $\mathbf{3 0 0}$ \\
\hline
\end{tabular}

Hasil penelitian ini memperlihatkan INP Kedelai- Refugia pada lahan pertanaman kacang kedelai. Tabel 2. Menunjukan nilai tertinggi adalah Cynodon dactylon L. dan Cyperus rotundus yaitu 138,92\% dan 68,61\%. Hal ini menunjukan, kedua jenis gulma tersebut memiliki pengaruh besar terhadap komunitas rumput di lahan pertanaman kacang kedelai. Pemilihan teknik pengendalian gulma dilokasi tersebut perlu memperhatikan karakter morfologi, fisiologi, dan kemampuan 
berkembangbiak kedua jenis gulma tersebut agar mendapatkan hasil yang efektif. Namun demikian, bukan berarti mengabaikan jenis gulma yang lain.

Sedangkan Hasil penelitian Gulma pada Lahan Refugia di lahan pertanaman kacang kedelai Menunjukan Nilai Penting.Tabel 3. Menunjukan nilai tertinggi adalah Cynodon dactylon L. dan Altnanthera sp. yaitu 37,38\% dan $21,73 \%$. Hal ini menunjukan, kedua jenis gulma tersebut memiliki pengaruh besar terhadap komunitas rumput di lahan pertanaman kacang kedela

Tabel 3. Nilai Penting Gulma pada Lahan Refugia di Lahan Pertanaman Kacang kedelai.

\begin{tabular}{lllll}
\hline Spesies & KR(\%) & FM(\%) & DM(\%) & INP \\
\hline Cynodon dactylon L. & 65,71 & 18,75 & 27,67 & 37,38 \\
Cyperus rotundus & 21,70 & 18,75 & 16,38 & 18,94 \\
Alternanthera sp. & 4,62 & 12,50 & 48,08 & 21,73 \\
Eleusine indica L. & 0 & 3,12 & 0 & 1,04 \\
Commelina diffusa Burm.F. & 0 & 3,12 & 0 & 1,04 \\
Portulaca oleracen L. & 0 & 9,37 & 0 & 3,12 \\
Amaranthus spinosus L. & 0,11 & 6,24 & 1,47 & 2,61 \\
Marselina minuta L. & 0,35 & 12,50 & 0,09 & 4,31 \\
Ischaemum rugosum Salisb. & 0,71 & 3,12 & 0,68 & 1,50 \\
Cyperus difformis L. & 6,76 & 12,50 & 5,59 & 8,28 \\
\hline TOTAL & 100 & 100 & 100 & 100 \\
\hline
\end{tabular}

\section{Indeks Keanekaragaman (H')}

Berdasarkan Hasil Analisis Vegetasi gulma pada lahan pertanaman kacang kedelai menunjukan hasil indeks keanekaragaman gulma yang rendah karena ratarata karena jumlah indeks keanekaragaman gulma pada lahan pertanaman kacang kedelai yaitu $<1$ Kategori sangat rendah.

Tabel 4. Indeks Keragaman Gulma- Refugia pada Lahan Pertanaman Kacang Kedelai.

\begin{tabular}{llc}
\hline Nama Spesies & INP & Indeks Keanekaragaman (H') \\
\hline Cynodon dactylon L. & 138,96 & 0,15 \\
Cyperus rotundus & 68,61 & 0,14 \\
Alternanthera sp. & 22,92 & 0,08 \\
Eleusine indica L. & 3,35 & 0,02 \\
Commelina diffusa Burm.F. & 3,22 & 0,02 \\
Portulaca oleracen L. & 11,50 & 0,05 \\
Amaranthus spinosus L. & 12,33 & 0,05 \\
Marselina minuta L. & 16,56 & 0,06 \\
Ischaemum rogusum salisb. & 3,12 & 0,02 \\
Cyperus difformis L. & 19,41 & 0,07 \\
\hline TOTAL & $\mathbf{3 0 0}$ & $\mathbf{0 , 7 4}$ \\
\hline
\end{tabular}

Indeks keanekaragaman spesies yang tinggi menunjukkan bahwa suatu komunitas memiliki kompleksitas tinggi karena interaksi spesies yang tinggi dalam 
komunitasnya dan jika komunitas itu disusun oleh banyak spesies dan sebaliknya, suatu komunitas dikatakan memiliki keanekaragaman spesies yang renda jika komunitas itu disusun oleh sedikit spesies dan jika hanya ada sedikit saja spesies yang dominan (Indriyanto, 2010). Lingkungan dengan indeks keanekaragaman rendah dapat dikatakan labil, karena didominasi oleh jenis tertentu dan ada jenis gulma tertentu yang mendesak kehidupan gulma yang lainnya (Odum, 1971).

Data indeks keanekaragaman Gulma-Refugia dapat dilihat pada Tabel 4.menunjukkan bahwa dari 10 spesies gulma pada lahan pertanaman kacang kedelai Menunjukan nilai Indeks Keanekaragaman Kategori rendah yaitu $<1$.

Sedangkan perbandingan Data indeks keanekaragaman Gulma pada Lahan Refugia di Lahan Pertanman Kacang Kedelai dapat dilihat pada Tabel 5 menunjukkan bahwa dari 10 spesies gulma pada lahan pertanaman kacang kedelai Menunjukan nilai Indeks Keanekaragaman Kategori rendah yaitu $<1$.

Tabel 5. Indeks Keanekaragaman Gulma pada Lahan Refugia di Lahan Pertanaman Kacang Kedelai.

\begin{tabular}{llc}
\hline Nama Spesies & INP & Indeks Keanekaragaman (H') \\
\hline Cynodon dactylon L. & 112,14 & 0,15 \\
Cyperus rotundus & 56,84 & 0,13 \\
Alternanthera sp. & 65,21 & 0,14 \\
Eleusine indica L. & 3,12 & 0,02 \\
Comme lina diffusa Burm.F. & 3,12 & 0,02 \\
Portulaca oleracen L. & 9,37 & 0,04 \\
Amaranthus spinosus L. & 7,84 & 0,04 \\
Marselina minuta L. & 12,95 & 0,05 \\
Ischaemum rugosum Salisb. & 4,52 & 0,02 \\
Cyperus difformis L. & 24,85 & 0,08 \\
\hline TOTAL & 300 & 0,72 \\
\hline
\end{tabular}

\section{Summed Dominance Ratio (SDR)}

Nilai SDR digunakan untuk menggambarkan jumlah dominansi suatu jenis gulma dengan jenis gulma lain dalam satu komunitas. Hasil data analisis SDR gulma Kedelai-Refugia pada pertanaman kacang kedelai gulma yang memiliki nilai SDR tertinggi pada areal pertumbuhan kacang kedelai yaitu terdapat pada golongan gulma rumput dan teki yaitu Cynodon dactylon L. dan Cyperus rotundus.

Keadaan tanaman kedelai yang sudah besar dan lebar sehingga melakukan penyiangan dengan cara manual yaitu dengan mencabuti gulma secara langsung. Cara seperti ini kurang efektif karena tunas gulma yang masih kecil sering kali terlewat. Cyperus rotundus memiliki sifat reproduksi sangat cepat. Sehingga pada penyiangan yang kurang teliti jenis Cyperus rotundus yang baru bertunas sering diabaikan (Yasir dan Mitikauji, 2007).

Tabel 6. Nilai Summed Dominance Ratio (SDR) Gulma Kedelai-Refugia pada Pertanaman Lahan Kacang Kedelai. 


\begin{tabular}{llc}
\hline Nama spesies & INP & $\begin{array}{c}\text { Summed Dominance } \\
\text { Ratio } \text { (SDR) }\end{array}$ \\
\hline Cynodon dactylon L. & 138,92 & $46,30^{*}$ \\
Cyperus rotundus & 68,91 & $22,87^{*}$ \\
Alternanthera sp. & 22,92 & 7,64 \\
Eleusine indica L. & 3,35 & 1,11 \\
Comme lina diffusa Burm.F. & 3,22 & 1,07 \\
Portulaca oleracen L. & 11,50 & 3,83 \\
Amaranthus spinosus L. & 12,33 & 4,11 \\
Marselina minuta L. & 16,56 & 5,52 \\
Ischaemum rugosum Salisb. & 3,12 & 1,04 \\
Cyperus difformis L. & 19,41 & 6,47 \\
\hline TOTAL & 300 & 100 \\
\hline
\end{tabular}

Keterangan : *= Menunjukan Nilai SDR tertinggi.

Hasil data analisis SDR gulma pada Lahan Refugia di Lahan Pertanaman kacang kedelai gulma yang memiliki nilai SDR tertinggi pada areal pertumbuhan kacang kedelai yaitu terdapat pada golongan gulma rumput dan teki yaitu Cynodon dactylon L. dan Alteranathera sp.

Tabel 7. Nilai Summed Dominance Ratio (SDR) Gulma pada Lahan Refugia di Lahan Pertanaman Kacang Kedelai.

\begin{tabular}{llc}
\hline Nama spesies & INP & $\begin{array}{c}\text { Summed Dominance Ratio } \\
\text { (SDR) }\end{array}$ \\
\hline Cynodon dactylon L. & 112,14 & $37,38^{*}$ \\
Cyperus rotundus & 56,84 & 18,94 \\
Alternanthera sp. & 65,21 & $21,73^{*}$ \\
Eleusine indica L. & 3,12 & 1,04 \\
Comme lina diffusa Burm.F. & 3,12 & 1,04 \\
Portulaca oleracen L. & 9,37 & 3,12 \\
Amaranthus spinosus L. & 7,84 & 2,61 \\
Marselina minuta L. & 12,95 & 4,31 \\
Ischaemum rugosum Salisb. & 4,52 & 1,50 \\
Cyperus difformis L. & 24,85 & 8,28 \\
\hline TOTAL & 300 & 100 \\
\hline
\end{tabular}

Gulma golongan teki banyak tumbuh di tempat terbuka atau tidak terkena matahari secara lanngsung seperti tumbuh dilahan pertanian yang tidak terlalu kering, ladang, kebun, tegalan, pinggir jalan, yang hidup sebagai gulma karena sangat susah untuk diberantas (Gunawan, 1998). Perbedaan jenis gulma disebabkan oleh terjadinya perbedaan pengolahan tanaman, antara lain pengaturan air dan pemupukan serta adanya perbedaan morfologi dan karakter tanaman penyusun yang dapat merubah mikroklimat sehingga menimbulkan respon yang berbeda pada jenis gulma (Mercado, 1979).

\section{Kesimpulan}


Berdasarkan hasil Analisis Vegetasi yang telah dilakukan, maka terdapat tiga kesimpulan yaitu Terdapat sepuluh jenis keanekaragaman gulma pada lahan pertanaman kacang kedelai yang teridentifikasi dalam penelitian ini yaitu, Cynodon dactylon L., Eleusine indica L., Ischaemum rugosum, Cyperus rotundus, dan Cyperus difformis L., Amaranthus spinosus L., Commelina diffusa Burm F., Marselina minuta., Portulaca oleracea L., dan Alternanthera sp. Nilai Summed Dominance Ratio (SDR), pada Kedelai-Refugia tertinggi, Cynodon dactylon (46,30\%) dan terendah Ischaemum rugosum (1,05\%). Sedangkan Gulma pada Lahan Refugia di Lahan Pertanaman Kacang kedelai yaitu Cynodon dactylon $(37,38 \%)$, Alterananthera sp $(21,73 \%)$ dan yang terendah Eleusine indica L. $(1,04 \%)$.

\section{Daftar Pustaka}

Aldrich R.J. and R.J. Kremer 1997. Principles in Weed Management. Second Edition. Iowa State University Press, Ames Iow.

Gunawan, D. 1998. Tumbuhan Obat Indonesia. Pusat Penelitian Obat Tradisional UGM. Yogyakarta.

Indriyanto. 2010. Ekologi Hutan. Bumi Aksara. Jakarta.

Kompas. 2012. Perbedaan Kedelai Lokal dan Kedelai Impor. Available at http://bisniskeuangan.kompas.com/.

Mercado, B.L. 1979. Introduction to Weed Science. Southeast Asian Regional Center for Graduate Study and Research in Agriculture(SEARCA),Leguna,Philippines.

Odum, E. P., 1971. Dasar-Dasar Ekologi. Edisi ketiga Gadjah Mada University Press. Yogyakarta.

Perdana EO, Chairul and Syam Z. 2013. Analisis Vegetasi gulma pada tanaman buah naga merah

(Hylocereus polyhizus L.) di kecamatan Batang Anai, Kabupaten Padang Pariaman, Sumatra Barat. Jurnal Biologi Universitas Andalas 2 (4): 242-248.

Rosanti, D. 2012. Taksonomi Gulma pada pada perkebunan Kacang Panjang Desa Sungai Pinang Kabupaten Banyuasin. Jurnal Sainsmatika. Vol 9(1).

Sebayang, H.T. 2004. Herbisida dan pengendalian gulma tanaman. FP-UB.

Sembodo, D.R.J. 2010. Gulma dan Pengelolaannya Edisi Pertama. Yogyakarta(ID): Graha Ilmu. 